\title{
Lactate Released by Müller Glial Cells Is Metabolized by Photoreceptors from Mammalian Retina
}

\author{
C. L. Poitry-Yamate, S. Poitry, and M. Tsacopoulos \\ Experimental Ophthalmology Laboratory and Department of Physiology, University of Geneva Medical School, \\ Centre Médical Universitaire, 1211 Geneva 4, Switzerland
}

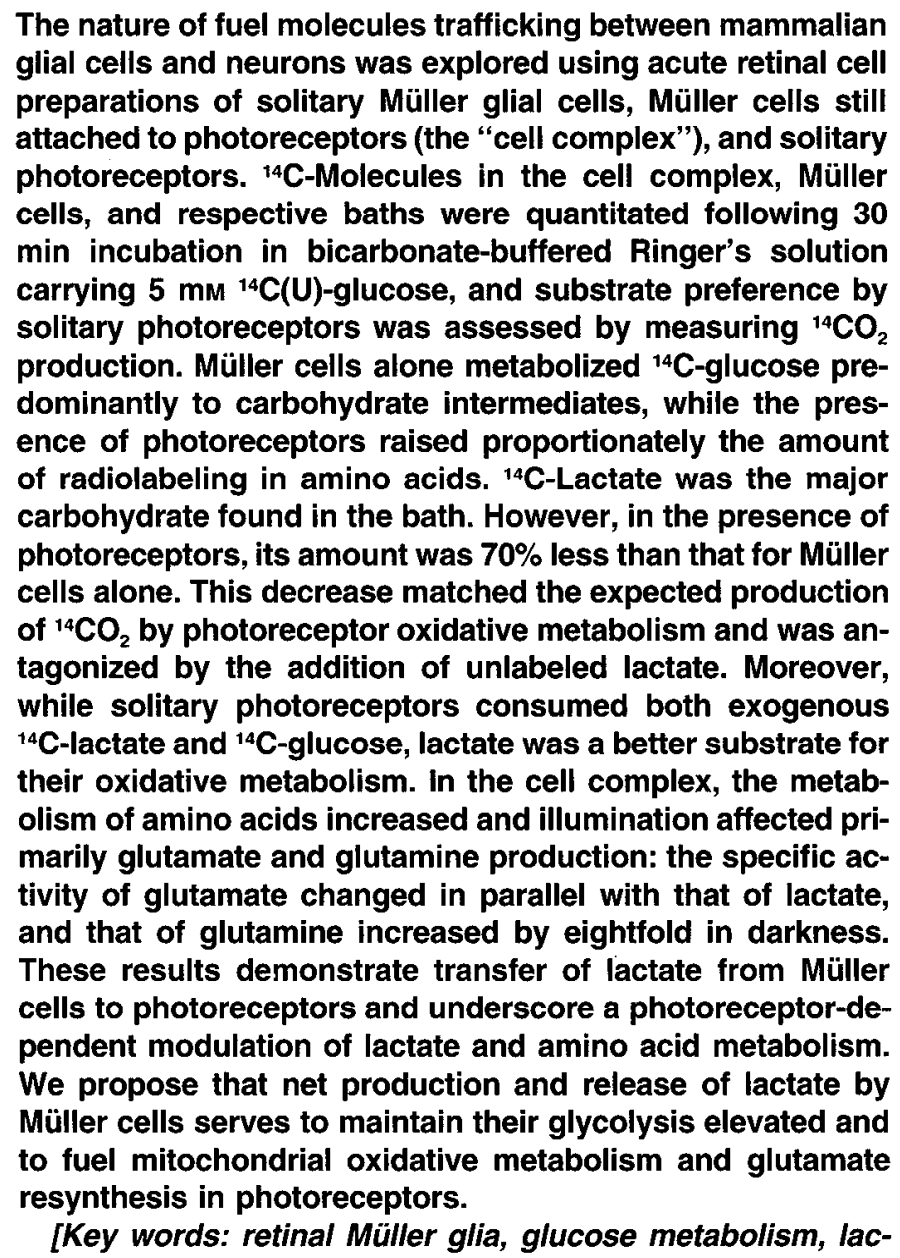
tate, photoreceptors, mitochondrial respiration, metabolic interaction, glutamate, glutamine, mammalian retina, noncultured cells]

Although glucose is the preferred substrate for brain and retina, there is accumulating evidence that lactate is an alternative substrate for energy metabolism in vertebrate nervous tissues (see,

\footnotetext{
Received Dec. 20, 1994; revised Feb. 23, 1995; accepted Feb. 23, 1995.

This work was supported by the Swiss National Science Foundation Grant 31-37587.93 and the Kernen Foundation. We thank the following for critically reading the manuscript: Drs. F. Assimacopoulos, P. J. Magistretti, W. Pralong, M. Prentki, J. Seydoux, and A. L. Veuthey.

Correspondence should be addressed to Dr. Carol Poitry-Yamate, Experi mental Ophthalmology Laboratory and Department of Physiology, University of Geneva Medical School, Centre Médical Universitaire, 1, rue Michel-Servet, 1211 Geneva 4, Switzerland.

Copyright (C) 1995 Society for Neuroscience $0270-6474 / 95 / 155179-13 \$ 05.00 / 0$
}

e.g., Larrabee 1983, 1992; Schurr et al., 1988). Recent evidence additionally points to the possibility of a cellular compartmentation of lactate metabolism and its trafficking from astroglia to neurones (Dringen et al., 1993; McKenna et al., 1993; Wiesinger et al., 1993; Pellerin and Magistretti, 1994). However, due to the structural complexity of the tissues, direct experimental evidence of transfer has yet to be demonstrated in the intact vertebrate nervous system, including the retina.

The isolated mammalian retina is known for its large production of lactate both in the presence and in the absence of oxygen (Krebs, 1972); for this reason, it is an appropriate preparation in which to ask why and by which type of retinal cell lactate production occurs. The finding that replacement of glucose by lactate in oxygenated Ringer's solution maintains retinal oxidative metabolism and photoreceptor function (Winkler, 1981) suggested the possibility that lactate, synthesized and released in situ by a retinal cell type having high glycolytic capacity, may be transferred to and metabolized by photoreceptors that have high respiratory capacity (Haugh et al., 1990).

Müller cells, the predominant glial element of vertebrate retina, intensively take up and phosphorylate glucose, part of which is stored as glycogen (Kuwabara and Cogan, 1961; Babel and Stangos, 1973; Poitry-Yamate and Tsacopoulos, 1991), and this metabolism as well as characteristic morphological features are retained by Müller cells acutely isolated from guinea pig retina (Poitry-Yamate and Tsacopoulos, 1992). This led us to measure the production of lactate from ${ }^{14} \mathrm{C}(\mathrm{U})$-glucose by solitary Müller cells. In addition, we describe here the development of both a model of solitary photoreceptors and a simple homogeneous model of Müller cells still attached to photoreceptors (the "cell complex"); that the spatial relationship and polarity of the cells are conserved after isolation of the cell complex makes this a novel model wherein possible trafficking of metabolites can still occur as they do in situ. Together with solitary Müller cells, these noncultured cell models were used to obtain quantitaive experimental evidence of metabolic trafficking of lactate and amino acids between glial cells and neurons.

We report here direct experimental evidence of a light-modulated transfer of glucose-derived lactate from Müller glial cells to photoreceptor neurons. This metabolic trafficking of substrate would serve to maintain glycolysis elevated in glial cells, and to fuel mitochondrial oxidative metabolism and glutamate resynthesis in photoreceptors, even in the presence of glucose. This trafficking is reminiscent of that of alanine recently demonstrated in insect retina (Tsacopoulos et al., 1994).

\section{Materials and Methods}

Animals

Sixty three pigmented guinea pigs (Cavia porcelus cobaya), between the ages of 5 and $12 \mathrm{~d}$, were used. Animals were supplied by the 

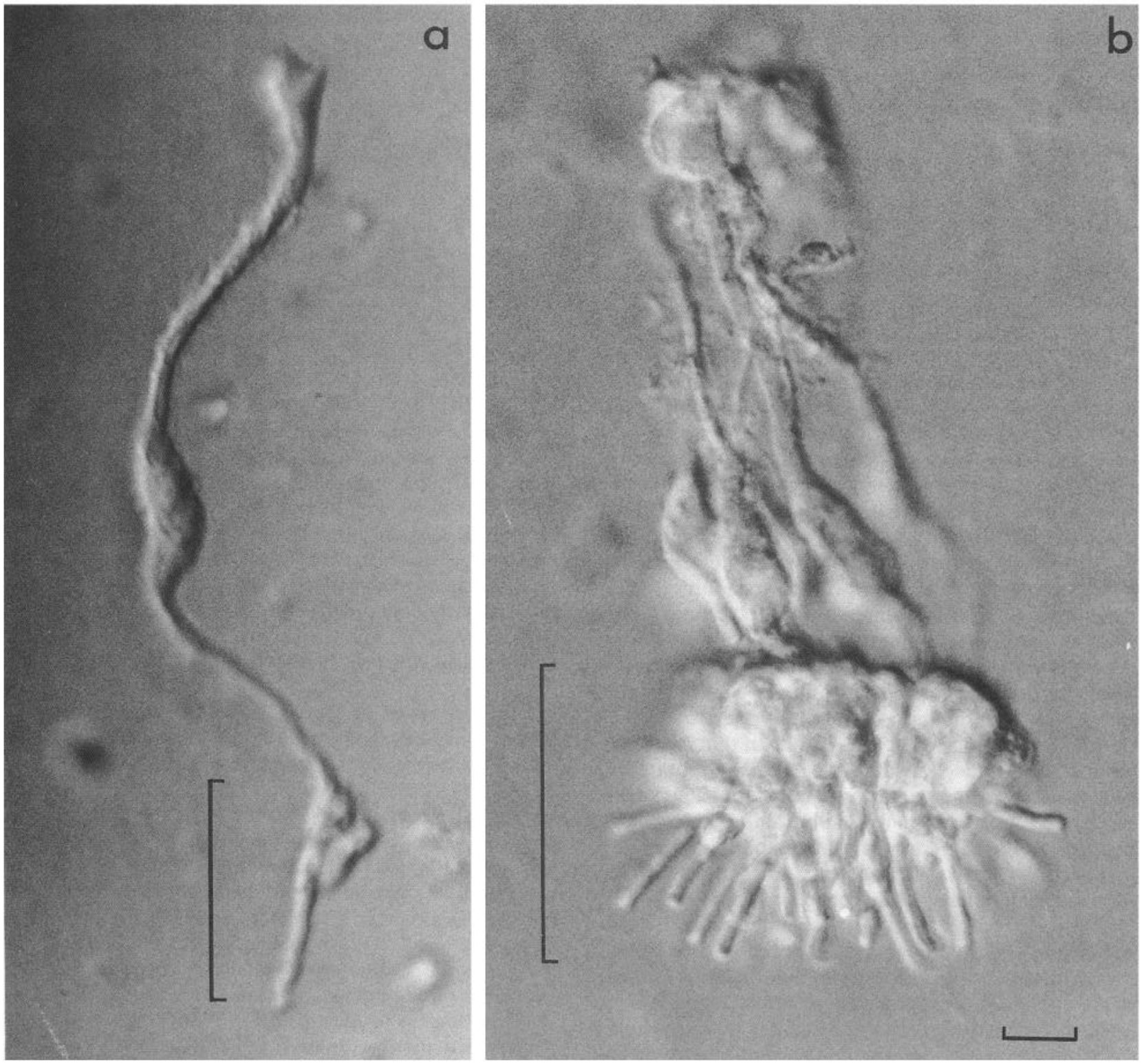

Figure 1. Müller cells still attached to photoreceptors (i.e., the cell complex) isolated from juvenile guinea pig retina. These cells, attached singly $(a)$ or in multiples $(b)$, are obtained with a milder trituration than Müller cells alone and are co-purified on a continuous Percoll gradient (see Materials and Methods). In this study, their metabolism of ${ }^{14} \mathrm{C}(\mathrm{U})$-glucose is quantitated and compared to that of solitary Müller glial cells shown in Figure 2. In the cell complex configuration, only photoreceptors, indicated by the vertical bars, contain photopigment and, hence, respond directly to illumination. Scale bar, $10 \mu \mathrm{m}$.

Zoo-tech-nie of Arare (Geneva, Switzerland), kept on a 12 hour light/dark cycle, and fed chow and water until sacrificed. Animals were lightly anesthetized with an intraperitoneal injection of sodium pentobarbital ( $30 \mathrm{mg} / \mathrm{kg}$ body weight) before decapitation.

\section{Reagents}

D[U- $\left.{ }^{14} \mathrm{C}\right]-$ Glucose (specific activity $292-320 \mathrm{mCi} / \mathrm{mmol}$ ) was obtained from Amersham (Hans Rahn \& Co, Zurich, Switzerland) and Dupont (Boston, MA). L[U-14 C]-Lactate (specific activity $108 \mathrm{mCi} / \mathrm{mmol}$ ) was obtained from Dupont. These radiolabeled substrates were analyzed by ion-exchange chromatography for purity, prior to use. Percoll, Batch No. 10211 (density $1.130 \mathrm{~g} / \mathrm{ml}$ ), was from Pharmacia (Uppsala, Sweden). Dowex 50W $\times 4\left(\mathrm{H}^{+}\right)$was from Fluka (Buchs, Switzerland) Enzymes used for retinal dissociations are indicated in a previous publication (Poitry-Yamate and Tsacopoulos, 1992). Microdetermination of total protein was performed using the method described by Markwell et al. (1981). Unless stated, all solutions for high-performance liquid chromatography (HPLC) were of HPLC grade. Phenylisothiocyanate (PITC) was purchased from Sigma Chemicals (Buchs, Switzerland) and Pierce (Socochim SA, Lausanne, Switzerland). Hexokinase (from yeast) was from Boehringer-Mannheim (Germany). Scintillation high flash point LSC-cocktail ("Ultima Gold") was purchased from Packard Instrument International SA (Zurich, Switzerland).

\section{Materials}

Eppendorfs with removable filters (Ultrafree-MC 0.22 and $0.1 \mu \mathrm{m}$ ) were purchased from Millipore AG (Volketswil, Switzerland). Scintillation tubes "Pico hang-in-vials" were from Packard Instrument International SA. Other plastic products were purchased from Milian Instruments SA (Geneva, Switzerland).

\section{Cell preparation}

Retinas of light-adapted animals were dissected out from the eye along with the retinal pigment epithelium and vitreous under red light as de- 

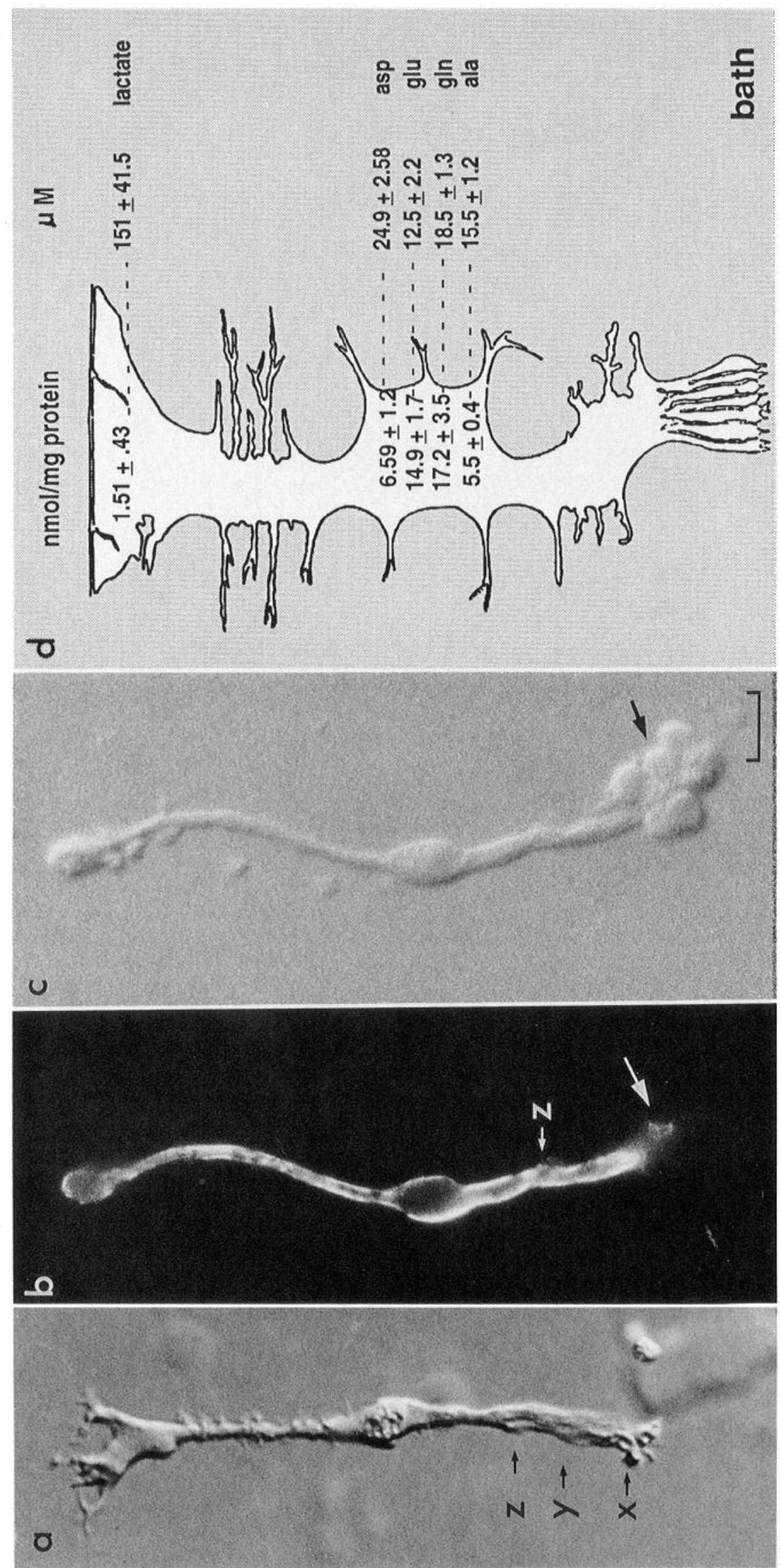

₹.

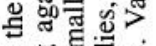

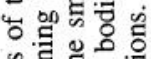

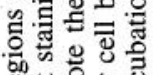
논은 ษั

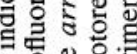

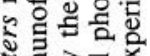
츨 호원 .

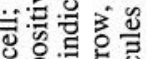
.

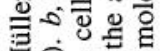
领此

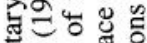

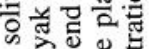
o

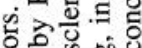
ㄴ.

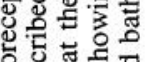
응 ํํㅁํㅇㅇำ

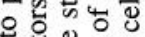
ᄃ 势 영 중 흐의 등 鄂进 ․․․․․․․

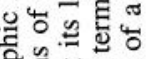
궁 on 0

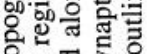
केष 氜

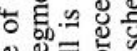

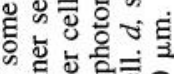

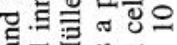

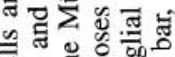
品

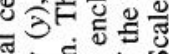
和主 $\geq 4$

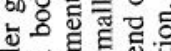
刍

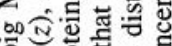
. 웅

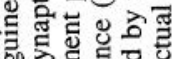
on

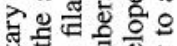

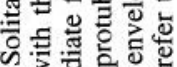
क

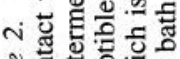

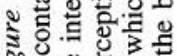
ำ 


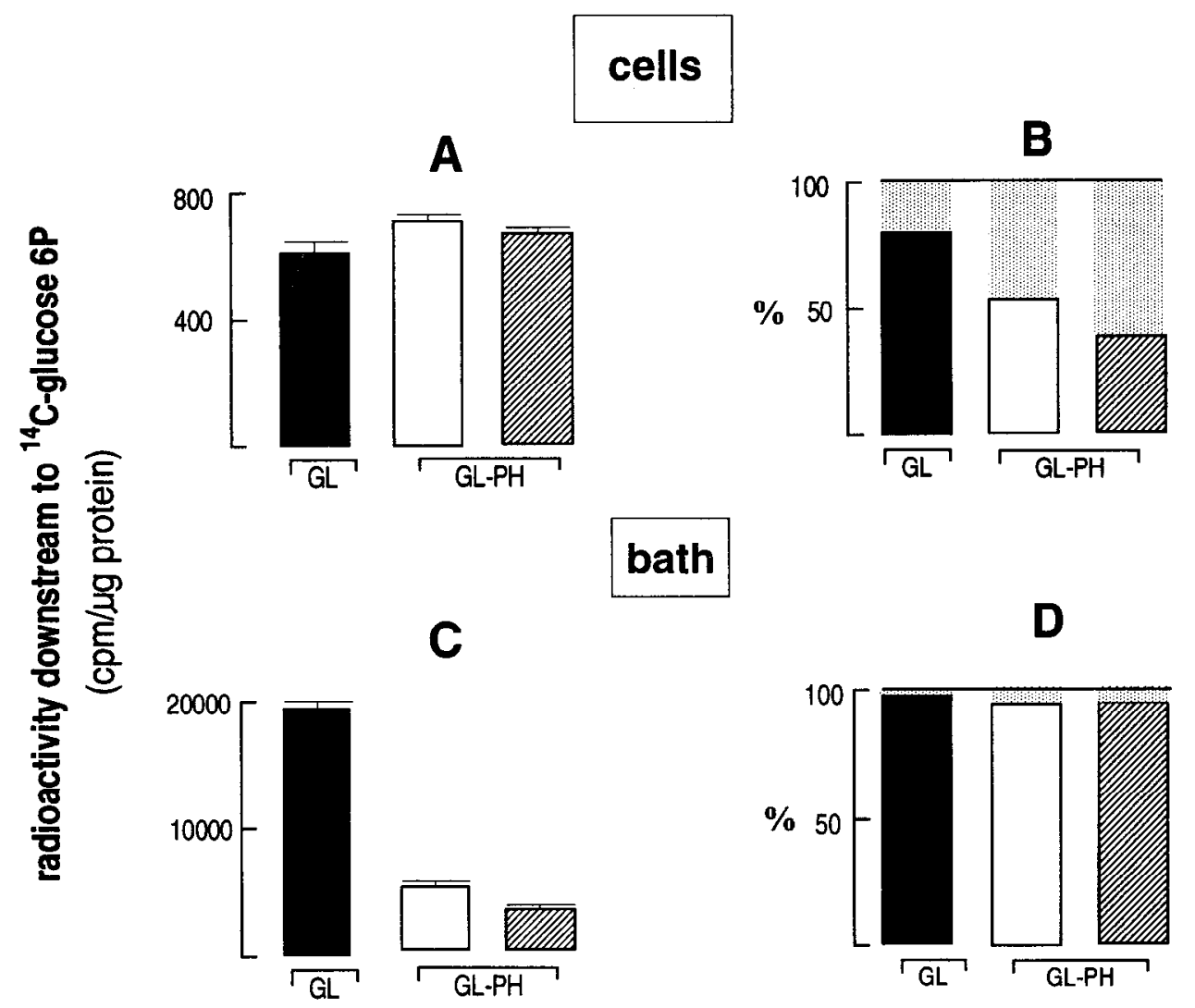

Figure 3. Amount of radioactivity downstream to ${ }^{14} \mathrm{C}(\mathrm{U})$-glucose- $6 \mathrm{P}$ in solitary Müller cells $(G L)$ and the cell complex $(G L-P H): A$, inside the cells; and $C$, in their corresponding baths. $B$ and $D$, Fractional amount of radioactivity in carbohydrate intermediates in $A$ and $C$, respectively. Dotted columns indicate the fractional amount of radioactivity in amino acids (this is best seen by turning the figure $180^{\circ}$ ). The fractional amount of radioactivity in amino acids in the bath was 5\% or less for both cell preparations. Black columns correspond to GL; open and hatched columns correspond to GL-PH maintained in light and darkness, respectively. Results are expressed as mean \pm SEM of 16 GL experiments and at least 7 light and 7 dark GL-PH experiments.

scribed in Poitry-Yamate and Tsacopoulos, (1992). Subsequent manipulations, using two retinas per cell preparation, were carried out in dim light (for part a) or in red light (for part b). It should be noted that "dim light" refers to the use of the strict minimum of indirect laboratory light necessary during the dissociation and purification procedure.

a. Solitary Müller cells $(G L)$ and Müller cells still attached to photoreceptors $(G L-P H)$. The mechanical dissociation and purification steps of the method established by Poitry-Yamate and Tsacopoulos (1992) for solitary Müller cells were modified to include Müller cells attached to photoreceptors, i.e. the "cell complex." First, milder and fewer triturations of retinas were used; second, the ratios "cell suspension": "solution A containing $\mathrm{Mg}^{2+}$ ": "Percoll (100\%)" were changed to 1:2.4: 1.6 (total volume, $5 \mathrm{ml}$ ) and centrifugation was performed at $8497 \times$ $g\left(10 \mathrm{~min}\right.$ at $\left.4^{\circ} \mathrm{C}\right)$. Purification time was thereby more than halved, the purity of each preparation was increased, and Muiller cell ramifications and photoreceptor outer segments were preserved. A single band of purified Müller cells alone was located two-thirds through the resultant gradient as before, and separated from a single band of the Müller cells attached to photoreceptors located $\approx 300 \mu \mathrm{l}$ below the Müller cell band. The resulting cell complex configuration, shown in detail in Figure 1, was obtained singly (Fig. 1a) or in multiples (Fig. 1b), similar to that occasionally observed in mice (Lolly et al., 1986) and rabbit (Reichenbach et al., 1989). Photoreceptors of the cell complex had the morphology of rods (Polyak, 1941) but the study by Altschuler et al. (1982) indicates that the number of cones is far from negligible. Hence, rods and cone photoreceptors were considered as both contributing to the cell complex. Photoreceptors in situ, unlike retinal neurones, "stick" to Müller cells by a junctional specialization, the zonulae adherentes (Hogan et al., 1971), a morphological landmark identifiable at the distal (scleral) end of solitary Müller cells ( $\mathrm{x}$ in Fig. 2). As further described by Polyak (1941) the scleral half of the Muiller cell, at the level of $z$ and $y$ in Figure 2, envelops the photoreceptor synaptic terminal and the cell perikaryon, respectively. As shown in Figure $2 b$ and $c$, the latter was confirmed after staining a cell complex devoid of outer segments with antibodies directed against the intermediate filament protein vimentin (see Poitry-Yamate and Tsacopoulos, 1992).

b. Solitary photoreceptors. Solitary photoreceptors were obtained by carrying out only the first step of the protocol used for obtaining Müller cells or the cell complex (i.e., exposure to collagenase; see Poitry-Yamate and Tsacopoulos 1992). This step detached the residual retinal pigment epithelium from the retina. Afterwards, retinas were transferred to $3 \mathrm{ml}$ of fresh standard Ringer's solution. They were then gently swirled and the surface of the scleral side gently puckered as described by Biernbaum and Bownds (1985). This movement effectively released solitary photoreceptors or small patches of these cells. Other retinal cells were very seldom released probably because the proximal retina was still protected by the overlying residual vitreous and inner retinal cells were still enveloped by Müller cells.

\section{Incubation}

Suspensions of solitary Müller cells or of Müller cells still attached to photoreceptors were washed in substrate-free Ringer's solution before incubation with ${ }^{14} \mathrm{C}$-glucose in light or darkness. Solitary Müller cells were maintained in darkness. Since there was some dim light present during the isolation procedure, rods of the cell complex may have been partially bleached. Hence, ${ }^{14} \mathrm{C}$-glucose incubations of GL-PH in darkness were probably less than optimal for maximally stimulating the metabolism of rods. Cell preparations (typical final concentrations of $13000 \mu \mathrm{g}$ of protein $/ \mathrm{ml}$ for Müller cells and of $6000 \mu \mathrm{g}$ protein $/ \mathrm{ml}$ for the cell complex) were bathed for $30 \mathrm{~min}$ at $37^{\circ} \mathrm{C}$ in $55 \mu \mathrm{l}$ of standard bicarbonate-buffered Ringer's solution (in mM: $\mathrm{NaCl}, 124 ; \mathrm{KCl}, 5$; $\mathrm{CaCl}_{2}, 2 ; \mathrm{KH}_{2} \mathrm{PO}_{4}, 1.25 ; \mathrm{NaHCO}_{3}, 20 ; \mathrm{MgSO}_{4}, 2 ; \mathrm{pH} 7.4 ; 95 \% \mathrm{O}_{2}, 5 \%$ $\mathrm{CO}_{2}$ ) carrying from between 5.1 and $5.3 \mathrm{~mm}$ D[U- $\left.{ }^{14} \mathrm{C}\right]$-glucose as substrate. ${ }^{14} \mathrm{C}$-glucose uptake and phosphorylation were stopped by rapid chilling of the cell chamber, and the cells and bath were separated as 

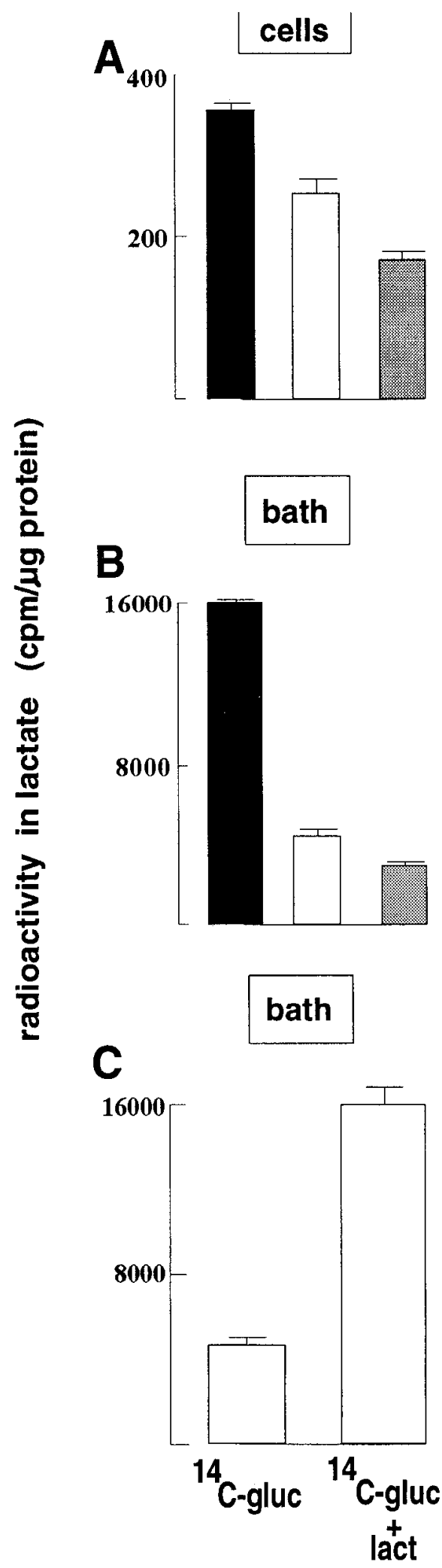

Figure 4. Radiolabeling of lactate from ${ }^{14} \mathrm{C}(\mathrm{U})$-glucose in solitary Müller cells and the cell complex: $A$, inside the cells, and $B$, in corresponding baths. Black columns correspond to GL; open and hatched columns correspond to GL-PH maintained in light and darkness, respectively. Results are expressed as mean \pm SEM and correspond to the experiments in Figure 3. Note the difference in scale between $A$ and $B$. $C$, Effect of adding nonlabeled lactate on ${ }^{14} \mathrm{C}$-lactate recovered in the bath of the cell complex maintained in light. Note that the scale is the same as in $B .{ }^{14} \mathrm{C}$-gluc; ${ }^{11} \mathrm{C}(\mathrm{U})$-glucose; lact, nonlabeled lactate. previously described (Poitry-Yamate and Tsacopoulos, 1992). In experiments designed to evaluate substrate preference by suspensions of solitary photoreceptors, the cells (typical final concentration of $30 \mu \mathrm{g}$ protein $/ \mathrm{ml}$ ) were preincubated in $400 \mu \mathrm{l}$ of Ringer's solution containing either $4 \mathrm{mM}$ D-glucose or $4 \mathrm{~mm} \mathrm{~L}$-lactate or both together for $20 \mathrm{~min}$. Thereafter, ${ }^{14} \mathrm{C}$-glucose (final concentration $75 \mu \mathrm{M}$ ) was added to the D-glucose-containing bath; ${ }^{14} \mathrm{C}$-lactate (final concentration $225 \mu \mathrm{M}$ ) was likewise added to the lactate-/or (lactate + glucose)-containing bath. ${ }^{14} \mathrm{CO}_{2}$ was collected on hyamine-impregnated filters for $60 \mathrm{~min}$ in darkness using the same microincubator as described by Tsacopoulos et al. (1994). The amount of ${ }^{14} \mathrm{C}$-substrates was adjusted so that the specific activity of lactate was the same as that of glucose. The results presented are corrected for the fact that the specific activity of $\mathrm{CO}_{2}$ produced from ${ }^{14} \mathrm{C}$-lactate is twice that of $\mathrm{CO}_{2}$ produced from ${ }^{14} \mathrm{C}$-glucose.

\section{HPLC preparation of cell homogenates and bath}

Cells were homogenized in $30 \%$ trichloroacetic acid, and after centrifugation, protein content of the sedimented pellet was measured and quantified as described by Markwell ct al. (1981). When necessary, the supernatant was divided into aliquots for the separate detection of metabolic intermediates and amino acids (see below).

Since ${ }^{14} \mathrm{C}$-glucose was used at a concentration of about $5 \mathrm{~mm}$, or 14 fold that used by Tsacopoulos et al. (1994), the chromatographic peaks corresponding to ${ }^{14} \mathrm{C}-\alpha$-ketoglutarate and ${ }^{14} \mathrm{C}$-pyruvate partially overlapped with that of ${ }^{14} \mathrm{C}$-glucose. Separation of ${ }^{14} \mathrm{C}$-pyruvate was improved by transforming enzymatically ${ }^{14} \mathrm{C}$-glucose to ${ }^{14} \mathrm{C}$-glucose-6phosphate (G6P). For this, samples were incubated in triethanolamine buffer $(50 \mathrm{mmol} / \mathrm{l})$ containing hexokinase and ATP at the necessary concentrations for $2 \mathrm{hr}$ at $37^{\circ} \mathrm{C}$; the reaction was stopped by rapid chilling and the samples were deproteinized by boiling. The results of this procedure showed that $\approx 80 \%$ of ${ }^{14} \mathrm{C}$-glucose was transformed to ${ }^{14} \mathrm{C}$ $\mathrm{G} 6 \mathrm{P}$, with no significant loss of radioactivity, and that ${ }^{14} \mathrm{C}-\mathrm{G} 6 \mathrm{P}$ still partially overlapped with ${ }^{14} \mathrm{C}-\alpha$-ketoglutaratc and a nonspecific peak introduced by the enzymatic reaction. For this reason, ${ }^{14} \mathrm{C}-\alpha$-ketoglutarate was not determined in the bathing medium. The total amount of pyruvate in cell homogenates was near the detection limits of the system and therefore difficult to quantify. For this reason, total pyruvate is not reported.

For the determination of amino acids, aliquots of the baths were desalted, since the presence of salts from the Ringer's solution interfered with the precolumn derivatizing agent, PITC. The method developed for desalting is similar to that described by Harris et al. (1961) but simpler. Briefly, this involved three passages through the same ion exchanger column (Dowex 50W $\times 4$ ion exchanger resin, $\mathrm{H}^{+}$form, 50100 mesh) at differing $\mathrm{pH}$ about the isoelectric points of glutamate (5.37) and glutamine (5.65). For the first passage, evaporated cell homogenates and baths were resuspended in $\mathrm{H}_{2} \mathrm{O}$ at $\mathrm{pH} 7.4(100 \mu \mathrm{l})$. Passage of this solution by centrifugation through the resin column eluted cations while retaining amino acids; this eluent was discarded. During the second passage, the retained amino acids were eluted by the addition of $\mathrm{NH}_{4} \mathrm{OH}$ at $\mathrm{pH} 11(2 \mathrm{~N}, 900 \mu \mathrm{l})$ followed by $\mathrm{H}_{2} \mathrm{O}(600 \mu \mathrm{l})$. This eluent was evaporated under vacuum. For the last passage, it was resuspended in $\mathrm{H}_{2} \mathrm{O}$, adjusted to $\mathrm{pH} 3.5$ with acetic acid. This final eluent was evaporated and stored at $-80^{\circ} \mathrm{C}$ until analysis. The recovery of aspartate, glutamate, glutamine, glycine, taurine, alanine, and proline was $>80 \%$. Desalted and normal standards of amino acids were injected at regular intervals between samples in the event of slight shifts in retention times. For each experiment, pool sizes of amino acids and metabolic intermediates were determined by integrating peak areas in chromatograms and calibrating with reference to injected standards.

Total concentrations in the cells are cxpressed in $\mathrm{nmol} / \mathrm{mg}$ cell proteins (N.B. intracellular concentrations may be roughly estimated by taking a ratio of $1 \mathrm{mg}$ of protein per $10 \mu \mathrm{l}$ of cell), and for the bath, the values refer to actual concentration. The fraction of a radiolabeled molecule is expressed as the specific activity (s.a.). For each experiment, values of s.a. were calculated by converting the amount of radioactivity $/ \mu \mathrm{g}$ cell proteins to $\mathrm{nmol} / \mathrm{mg}$ cell proteins and then dividing this value by the total pool size [e.g., $n \mathrm{cpm} / \mu \mathrm{g}$ cell proteins $\times(45 \mathrm{dpm} / 40 \mathrm{cpm})$ $\times\left(1 \mu \mathrm{Ci} / 2.22 \times 10^{6} \mathrm{dpm}\right) \times(1 \mu \mathrm{mol} / 146 \mu \mathrm{Ci}) \times(1000 \mu \mathrm{g}$ cell proteins/mg cell proteins)]. Note that because $392 \mu \mathrm{Ci} / \mu \mathrm{mol}$ is the s.a. of ${ }^{14} \mathrm{C}(\mathrm{U})$-glucose, the s.a. of a molecule downstream to glyceraldehyde3 -phosphate is $146 \mu \mathrm{Ci} / \mu \mathrm{mol}$. The percent of radioactivity downstream to ${ }^{14} \mathrm{C}-\mathrm{G} 6 \mathrm{P}$ in one type of molecule is expressed as the ratio of the radioactivity in this type of molecule to the radioactivity recovered in all the molecules other than ${ }^{14} \mathrm{C}$-glucose and ${ }^{14} \mathrm{C}$-G6P [the term "down 

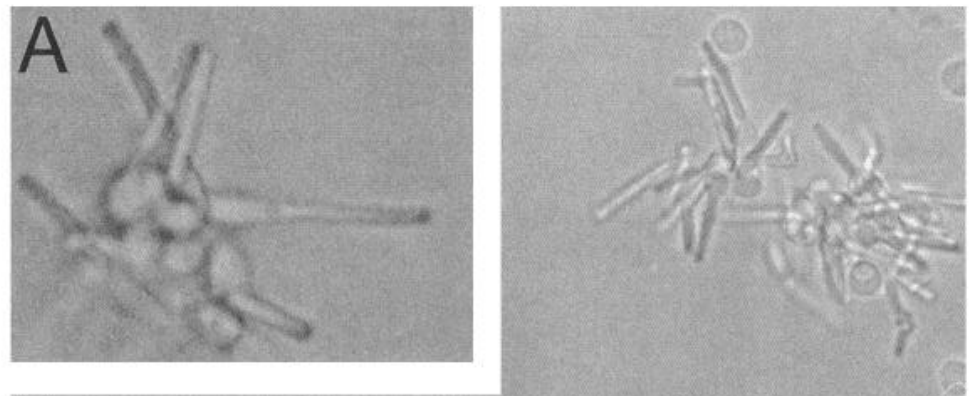

Figure 5. Production of ${ }^{14} \mathrm{CO}_{2}$ from ${ }^{14} \mathrm{C}(\mathrm{U})$-glucose and ${ }^{14} \mathrm{C}(\mathrm{U})$-lactate by solitary photoreceptors. A, Solitary photoreceptors isolated from guinea pig retina. Scale bar: $50 \mu \mathrm{m}$. Inset: detailed view of photoreceptors, approximately three times larger than main photo. $B$, production of ${ }^{14} \mathrm{CO}_{2}$ from one of three mixtures of substrates: a) $4 \mathrm{~mm}$ glucose and $75 \mu \mathrm{M}{ }^{14} \mathrm{C}$-glucose; b) 4 $\mathrm{mm}$ lactate and $225 \mu \mathrm{M}{ }^{14} \mathrm{C}$-lactate; or c) $4 \mathrm{~mm}$ glucose, $4 \mathrm{~mm}$ lactate, and 225 $\mu \mathrm{M}{ }^{14} \mathrm{C}$-lactate. Results are expressed as mean \pm SEM of at least three separate experiments. cpm* corresponds to measured $\mathrm{cpm}$, corrected for the fact that the specific activity of $\mathrm{CO}_{2}$ produced from glucose is only half that of $\mathrm{CO}_{2}$ produced from lactate; hence, raw $\mathrm{cpm}$ values from ${ }^{14} \mathrm{C}$-glucose were doubled.

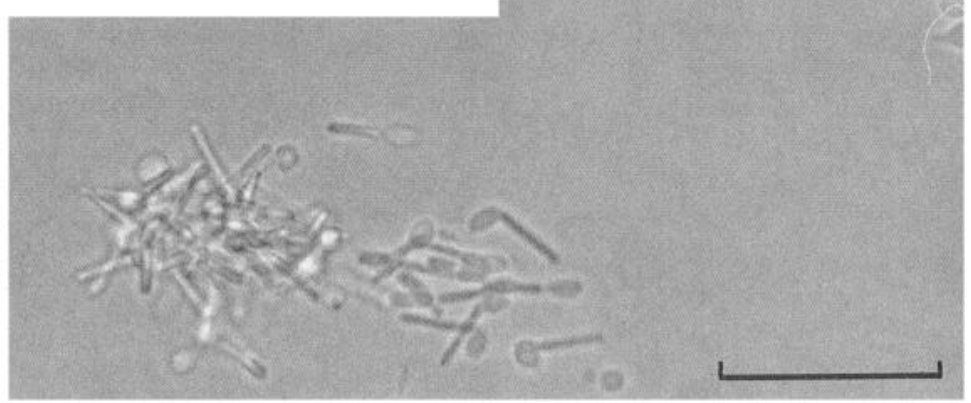

B

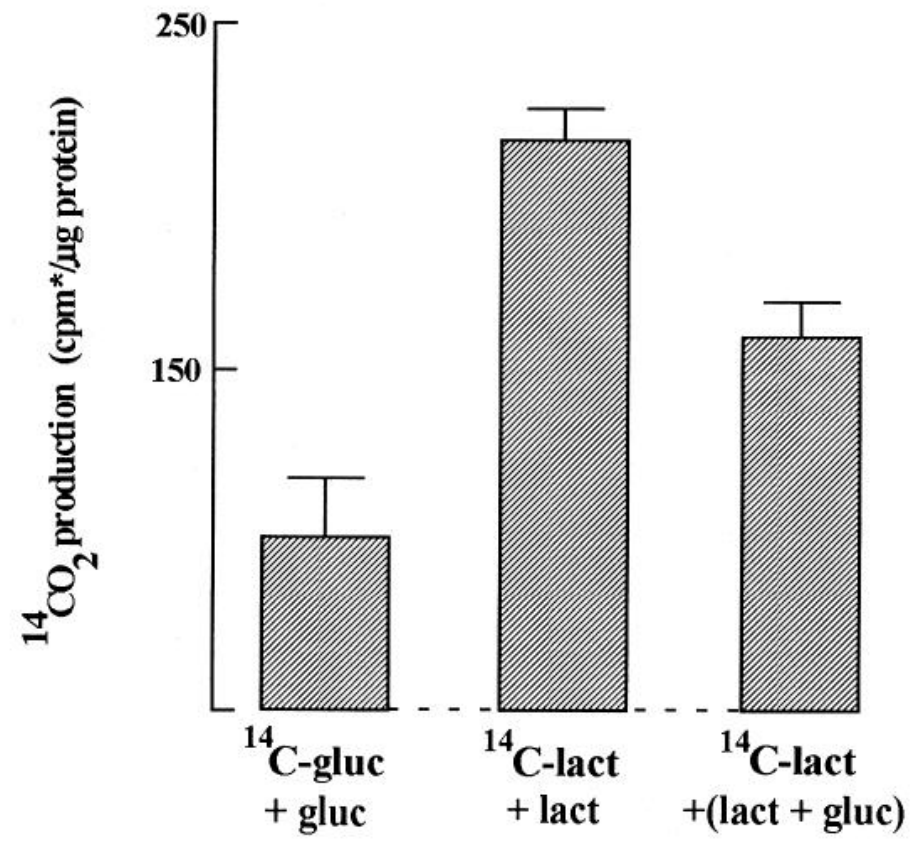

injection, the radioactive eluent was collected every $30 \mathrm{sec}$ on a fraction collector during $40 \mathrm{~min}$ and counted as previously described (PoitryYamate and Tsacopoulos, 1992).

Amino acids. Analysis of amino acids with ultraviolet detection (UV) and precolumn derivatization using PITC was performed using the system described in Tsacopoulos et al. (1994). This method was modified in the following way: the mobile phase consisted of 93 parts $\mathrm{Na}$ acetate ( $35 \mathrm{~mm}, \mathrm{pH}=5)$ and 7 parts acetonitrile, and the flow rate was 0.7 $\mathrm{ml} / \mathrm{min}$ through a Nucleosil C18 $(5 \mu \mathrm{m})$ (Macherey Nagel, Oensingen, Switzerland) reverse phase column at room temperature. When standards of ${ }^{14} \mathrm{C}$-glucose or metabolic intermediates of interest were derivatized and then injected into this system, no contaminating peaks were detected. The difference between the injected and eluted radioactivity from the column indicated a recovery of $\approx 90 \%$. Homocysteine was added during precolumn derivatisation as an internal standard. However, because there was an endogenous amino acid eluting at the same time in Müller cells, we looked for alternative standards. For this, we used 


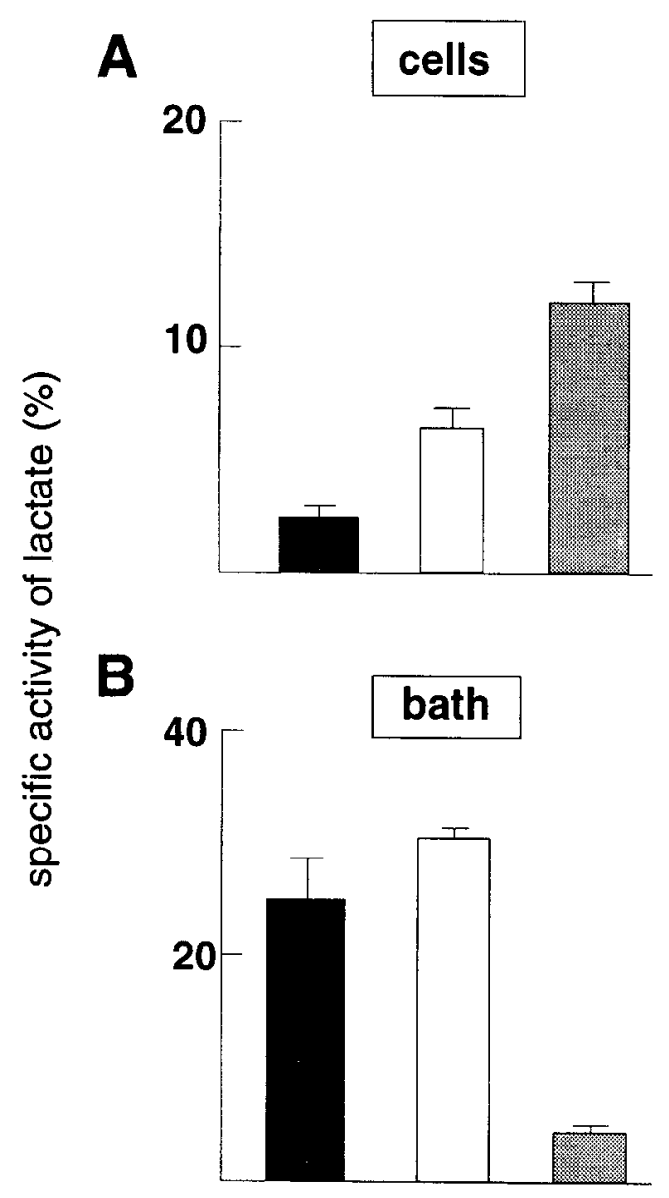

Figure 6. Specific activity (s.a.) of lactate in Müller cells and the cell complex. A, Values obtained inside the cells. $B$, Values obtained in corresponding bath. Black columns refer to GL; open and gray columns refer to GL-PH maintained in light and darkness, respectively. Results are expressed as mean \pm SEM and correspond to the experiments in Figure 3. Note the difference in scale between $A$ and $B$.

endogenous alanine for solitary Müller cells and endogenous taurine for the cell complex because the concentrations of these amino acids were stable from one experiment to another. Fractions of radioactive eluent per injection were collected every $12 \mathrm{sec}$ during $20 \mathrm{~min}$ and counted as described in Poitry-Yamate and Tsacopoulos (1992). Since the aim of this article is to determine which ${ }^{14} \mathrm{C}$-glucose metabolites produced in glia are released and transferred to neurons, levels of total radioactivity are explicitly reported.

\section{Results}

I. Metabolites synthesized from $D\left[U_{-}^{14} C\right]$-glucose in Müller cells $(G L)$ and the cell complex $(G L-P H)$

Following $30 \mathrm{~min}$ incubation in the presence of $\mathrm{D}\left[\mathrm{U}-{ }^{14} \mathrm{C}\right]-$ glucose, levels of radioactivity downstream to ${ }^{14} \mathrm{C}-\mathrm{G} 6 \mathrm{P}$ (i.e., in metabolites other than glucose and G6P) in Müller cells and in the cell complex were similar (Fig. $3 A$ ). The corresponding cell baths, on the other hand, contained levels of radioactivity that were $>$ fivefold lower for the cell complex than for Müller cells (Fig. $3 C$ ). In addition, the amount of radiolabeling was at least fourfold higher in the bath than inside the cells. This led us to ask whether there were differences in the types (classified here as either carbohydrate intermediates or amino acids) and proportion of radiolabeled molecules. As shown in Figure $3 B$ and $D$, this was indeed the case: taking $100 \%$ as the radioactivity recovered in all the molecules other than ${ }^{14} \mathrm{C}$-glucose and ${ }^{14} \mathrm{C}$ $\mathrm{G} 6 \mathrm{P},>95 \%$ of the radiolabeled molecules in the bath of both preparations was carried by carbohydrate intermediates. This proportion fell to less than $80 \%$ in the cells: amino acids carried at least $20 \%$ of the radiolabel inside Müller cells, and this proportion more than doubled inside the cell complex. Thus, Müller cells metabolize ${ }^{14} \mathrm{C}$-glucose principally into ${ }^{14} \mathrm{C}$-carbohydrate intermediates, while the presence of photoreceptors, either in light or in darkness, modifies this proportion by raising the amount of radiolabeling in amino acids. The results shown in Figure $3 C$ and $D$ clearly indicate that Müller cells release ${ }^{14} \mathrm{C}$ carbohydrate intermediates, and that when photoreceptors are present, either the synthesis, release or metabolic fate of these molecules is modified. Moreover, the fact that the overall (cell plus bath) recovery of radiolabel was considerably less for the cell complex than for solitary Müller cells indicates that radiolabel must have appeared in a molecule other than the carbohydrate intermediates and amino acids, possibly in $\mathrm{CO}_{2}$. The questions that we address in the next sections in regards to the foregoing observations are (1) what is the identity of the carbohydrate intermediates released by Müller cells; (2) is one of these molecules eventually taken up and transformed by photoreceptors of the cell complex; and (3) if so, is this transformation linked to both the rise in the proportion of radiolabeled amino acids in the cell complex maintained in darkness and the loss of radiolabeling in the corresponding bath?

\section{Radiolabeling of lactate in Müller cells and the cell complex}

Upon examining in detail the magnitude of radiolabeling of individual carbohydrate intermediates in both cell preparations, we found that intermediates such as $\alpha$-ketoglutarate, pyruvate and malate were labeled inside the cells, and that for solitary Miiller cells, some ${ }^{14} \mathrm{C}$-pyruvate was released into the bath (results not shown). However, the striking observation was that most of the radiolabeling in carbohydrate intermediates inside the cells and in the baths was carried by ${ }^{14} \mathrm{C}$-lactate $(>65 \%$ and $>85 \%$, respectively) (compare Figs. 3, 4).

This finding is consistent with the idea that lactate is an end product of glycolysis and, therefore, accumulates. Since photoreceptors depend for their functioning on oxidative metabolism (Ames et al., 1992), it is expected that they produce little if any lactate. Hence, the decrease of ${ }^{14} \mathrm{C}$-lactate inside the cell complex relative to that inside Müller cells may be due to the presence of photoreceptors in the cell complex. However, the fact that ${ }^{14} \mathrm{C}$-lactate decreases proportionately more in the bath of the cell complex than in the cells (Fig. $4 A, B$ ), and that in solitary Müller cells there is a massive and rapid metabolism of glucose to lactate, which is released into the bath (Fig. $4 A, B$, left side), raises the question as to whether this extracellular lactate, in turn, fuels the mitochondrial oxidative metabolism in photoreceptors. This view is supported by a quantitative analysis of the data. Taking that photoreceptors, which constitute about $50 \%$ of the preparation, are the major contributors to $\mathrm{CO}_{2}$ production and that their oxygen consumption in darkness is of about 40 $\mu \mathrm{l} \mathrm{O}$ /gram min (average for mammals at $37^{\circ} \mathrm{C}$, see Ahmed et al., 1993), we calculated that photoreceptors in the cell complex would incorporate about $13,000 \mathrm{cpm} / \mu \mathrm{g}$ protein into $\mathrm{CO}_{2}$ after $30 \mathrm{~min}$. This value corresponds roughly to the drop in ${ }^{14} \mathrm{C}$-lactate observed in Figure 4 . In addition, ${ }^{14} \mathrm{C}$-lactate decreased less both in the cells and in the bath of the cell complex maintained in light, a condition wherein the oxidative metabolism of photoreceptors is lowered. This difference between light and darkness was not as large as would be predicted probably because, with 
the incubation conditions used here, only cones (as opposed to rods) were fully responsive.

This working hypothesis was further tested by performing the following experiment: the cell complex maintained in light was incubated exactly as before, except that $4 \mathrm{~mm}$ nonradiolabeled lactate was added to the incubation medium. Considering that the addition of this substrate to the medium should compete with radiolabeled lactate for transport into photoreceptors, the prediction, if our hypothesis is correct, is that most, if not all, of the radiolabeled lactate should then appear in the bath. The results of four separate experiments show that this was indeed the case (right-hand column of Fig. $4 C$; the left-hand column is the same as the empty column in Fig. $4 B$ ). Hence, it appears that lactate in the bath of the cell complex is consumed and that the decrease in ${ }^{14} \mathrm{C}$-lactate relative to the bath of solitary Müller cells is due to lactate consumption by photoreceptors. Dircet cvidence for this is presented below.

\section{Production of ${ }^{14} \mathrm{CO}_{2}$ by solitary photoreceptors}

To determine whether lactate fuels oxidative metabolism in photoreceptors and whether it is preferred over glucose, we isolated photoreceptor cells from the guinea pig retina and measured their production of ${ }^{14} \mathrm{CO}_{2}$ from ${ }^{14} \mathrm{C}(\mathrm{U})$-glucose or ${ }^{14} \mathrm{C}(\mathrm{U})$-lactate. Isolated photoreceptors such as those shown in Figure $5 \mathrm{~A}$ were incubated in darkness for $60 \mathrm{~min}$ in Ringer's solution containing one of three mixtures of substrates. The results clearly show that both ${ }^{14} \mathrm{C}$-glucose and ${ }^{14} \mathrm{C}$-lactate are consumed by photoreceptors (Fig. 5B, left and middle columns). However, lactate appears to be a better substrate since the amount of ${ }^{14} \mathrm{CO}_{2}$ produced from ${ }^{14} \mathrm{C}$-lactate decreased only by about $25 \%$ when equimolar amounts of glucose were added (see Fig. $5 B$, middle and right columns). Hence, while photoreceptors consume both lactate and glucose, lactate is apparently a better substrate for their oxidative metabolism.

The amount of ${ }^{14} \mathrm{CO}_{2}$ produced from ${ }^{14} \mathrm{C}$-lactate corresponded to an oxygen consumption about 10 times lower than that of photoreceptors in the retina (see, e.g., Ahmed et al., 1993). On the other hand, as described in section II, the amount of lactate recovered in the bath of the cell complex, when compared to that of solitary Müller cells, was decreased by an amount compatible with the oxygen consumption of photoreceptors. This discrepancy suggests that, in the cell complex, Muiller cells release, in addition to lactate, other molecules that stimulate oxidative metabolism in photoreceptors.

\section{Specific activity of lactate in Müller cells and the cell complex}

Since Müller cells contain the predominant stores of retinal glycogen (Poitry-Yamate and Tsacopoulos, 1991), a natural question to ask at this point is whether lactate is also produced from glycogen stores of Müller cells. To this end, for the experiments already presented in Figure 4, we also measured the total amount of lactate produced in Müller cells and in the cell complex and then used these values to calculate the corresponding specific activity (s.a.) of lactate. The s.a. reported here is the ratio of labeled metabolite to labeled plus nonlabeled metabolite; therefore, the higher the s.a., the higher is the contribution of exngenous glucose to the formation of the metabolite. For solitary Müller cells (left-hand column of Fig. $6 A, B$ ), the s.a. of lactate was considerably higher in the bath than in the cells. This result indicates that in Muiller cells lactate can be produced from exogenous ${ }^{14} \mathrm{C}$-glucose and from an endogenous and poorly labeled source, such as glycogen, but that it is the lactate produced from exogenous glucose that is rapidly released into the hath. On the other hand, for the cell complex, the presence of light-adapted photoreceptors led to a rise in the s.a. of lactate inside the cells, but not to a significant change in the s.a. of lactate in the bath (middle columns in Fig. 6). This was in sharp contrast to the results obtained in the presence of dark-adapted photoreceptors: the s.a. of lactate inside the cells increased further, but that in the bath decreased by $>$ sixfold (right columns in Fig. $6 \mathrm{~B}$ ). This last observation is consistent with the idea that lactate produced from glycogen stores is then released in larger quantities into the bath. In other words, in darkness, an increased metabolism in photoreceptors would lead to a stimulation of glycogenolysis in Müller cells.

\section{$V$. Radiolabeling and specific activity of amino acids in Müller cells and the cell complex}

The observations (Fig. 3) that amino acids contributed proportionately more to the radiolabeling in the cell complex than in Müller cells alone, and that lactate produced from glucose serves as a fuel for photoreceptor oxidative metabolism, led us to make a more detailed analysis of the incorporation of radiolabel into amino acids. This was especially interesting since the potent neurotransmitter glutamate (for review, see Massey 1990), can be taken up by Müller cells (Barbour et al., 1991) and then transformed into glutamine (Riepe and Norenberg, 1977).

In solitary Müller cells, radioactivity was found mostly in aspartate, glutamate, glutamine, and alanine (Fig. $7 a, d$ ). Together, they amounted to about $80 \%$ of the radiolabeled amino acids in the bath and to $>50 \%$ inside the cells. Other radiolabeled amino acids included arginine, proline, and glycine (results not shown). Interestingly, the total amount of ${ }^{14} \mathrm{C}$-amino acids was larger in the bath than inside the cells.

These results are in contrast to those obtained for the cell complex: for this preparation, the total amount of ${ }^{14} \mathrm{C}$-amino acids was larger inside the cells than in the bath (Fig. $7 b, c, e, f$ ). In addition, the levels of individual ${ }^{14} \mathrm{C}$-amino acids inside the cells of the cell complex were larger than inside solitary Müller cells (Fig. $7 a-c$ ), and the converse was observed in the bath (Fig. $7 d$ $f$ ). This may indicate that amino acid metabolism is predominantly localized to photoreceptors and dependent on their oxidative metabolism.

If we now turn to the effect of illumination on the amino acids of the cell complex, it is clear that this effect is principally seen in the radiolabeling of glutamate and of glutamine inside the cells (Fig. $7 b, c$ ); indeed, the radioactivity in these molecules more than doubled in darkness.

In order to examine the extent to which amino acids were labeled and how this was modified by illumination, we measured in the same experiments the total amount of aspartate, glutamate, glutamine, and alanine produced in Müller cells and in the cell complex, and then used these values to calculate the corresponding s.a. (Fig. 8). Four major observations can be drawn from these results: first, the s.a. of the four amino acids shown was higher for the cell complex than for solitary Müller cells (note the difference in scale between the two preparations in Fig. 8), a demonstration that the metabolism of amino acids was increased in the presence of photoreceptors. Second, for solitary Müller cells, the s.a. of glutamine was 20 -fold higher in the bath than inside the cells; hence, the newly formed glutamine appears to be preferentially released, an observation similar to that made for lactate in section IV. Third, the s.a. of glutamine inside Müll- 


\section{cells}

a.

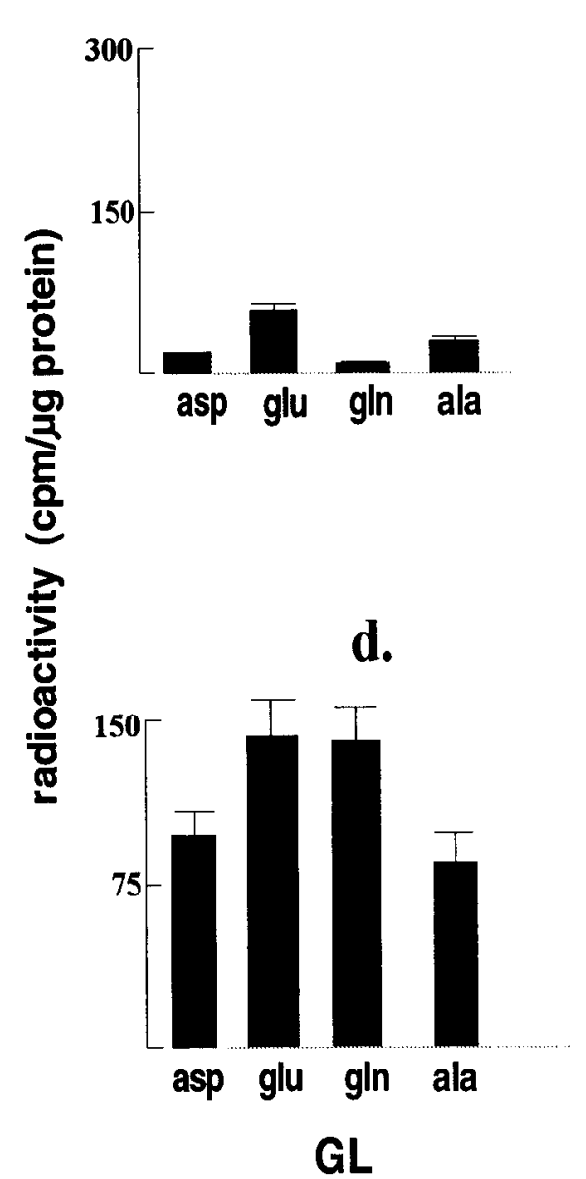

b.

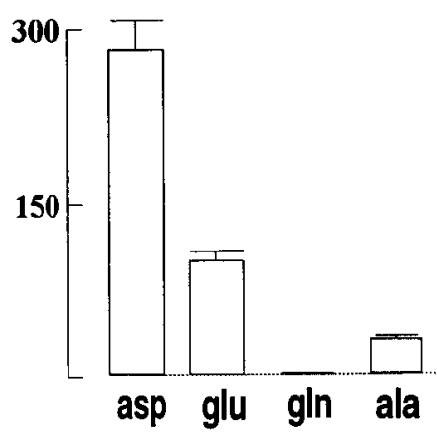

bath

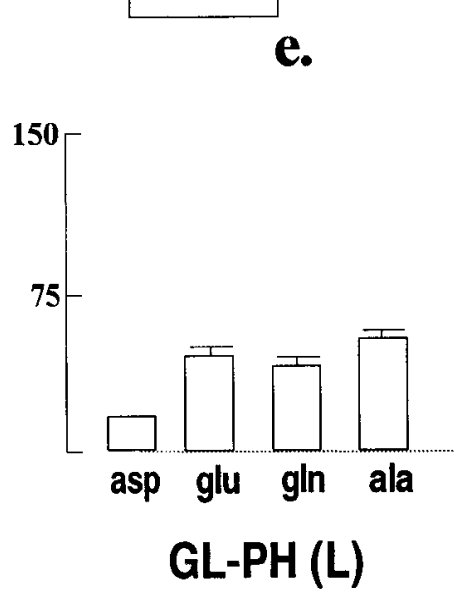

c.

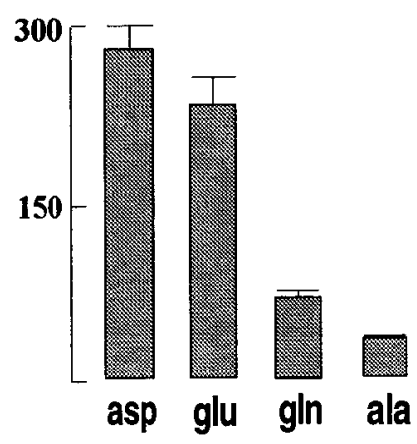

f.

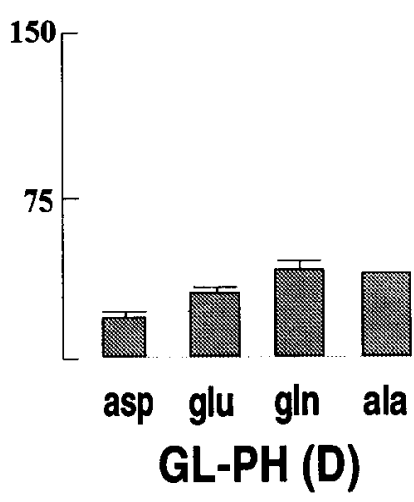

Figure 7. Radiolabeling of amino acids from ${ }^{14} \mathrm{C}(\mathrm{U})$-glucose. Upper panel: inside the cells. Lower panel: in corresponding baths; $a$ and $d$, for Müller cells; $b$ and $e$, for the cell complex maintained in light; $c$ and $f$, for the cell complex maintained in darkness. Results are expressed as mean \pm SEM and correspond to the experiments in Figure 3. Error bars not indicated when SEM was smaller than top border of columns. Note the difference in scale between the upper and lower panels. asp, aspartate; glu, glutamate; gln, glutamine; ala, alanine.

er cells and the cell complex maintained in light was similar but increased eightfold in darkness, consistent with a stimulation of glutamine formation in this condition. Finally, the s.a. of glutamate inside the cell complex rose in darkness, while this was the converse in the bath; this particular observation is reminiscent of the changes in the s.a. of lactate, and raises the possibility that glutamate formation is tightly linked to lactate metabolism.

\section{Discussion}

In this study, solitary Müller glial cells, Müller cells still attached to photoreceptors (the cell complex), and solitary photoreceptors were acutely isolated from mature guinea pig retina and used as mammalian CNS models for quantitative evaluation of metabolic interactions between glial cells and neurones.

The chief results that have been obtained are (1) solitary Müller cells synthesize and release predominantly lactate, but also amino acids and Kreb's cycle intermcdiates; (2) as mcasurcd by the production of $\mathrm{CO}_{2}$, lactate is a better substrate than glucose for the mitochondrial oxidative metabolism of solitary photoreceptors; (3) in the cell complex, the metabolism of lactate, glu- tamate, and glutamine is modulated by light, in a manner compatible with a light-modulated trafficking of these molecules between glia and photoreceptor-neurons (see Fig. 9).

\section{Even in the presence of glucose, lactate released by Müller cells fuels the oxidative metabolism in photoreceptors}

Our finding that $>90 \%$ of the lactate produced by solitary Muiller cells from exogenous glucose was found in the bath, and that the s.a. of this lactate was considerably higher than that inside the cells, indicates that lactate is readily and preferentially released from Müller cells. To our knowledge, these results are the first to demonstrate the production and release of lactate by Muiller glial cells of the retina under aerobic conditions. In this regards, the isolated mammalian retina produces lactate aerobically and anaerobically (Krebs, 1972), but the former is probably restricted to Müller cells since they contain few mitochondria (Uga and Smelser, 1973). Moreover, M LDH, the isoenzyme form of lactate dehydrogenase associated with pyruvate reduction, is localized to the inner layers of the retina (Matchinsky, 1970) and Muiller cells extend through these layers. 


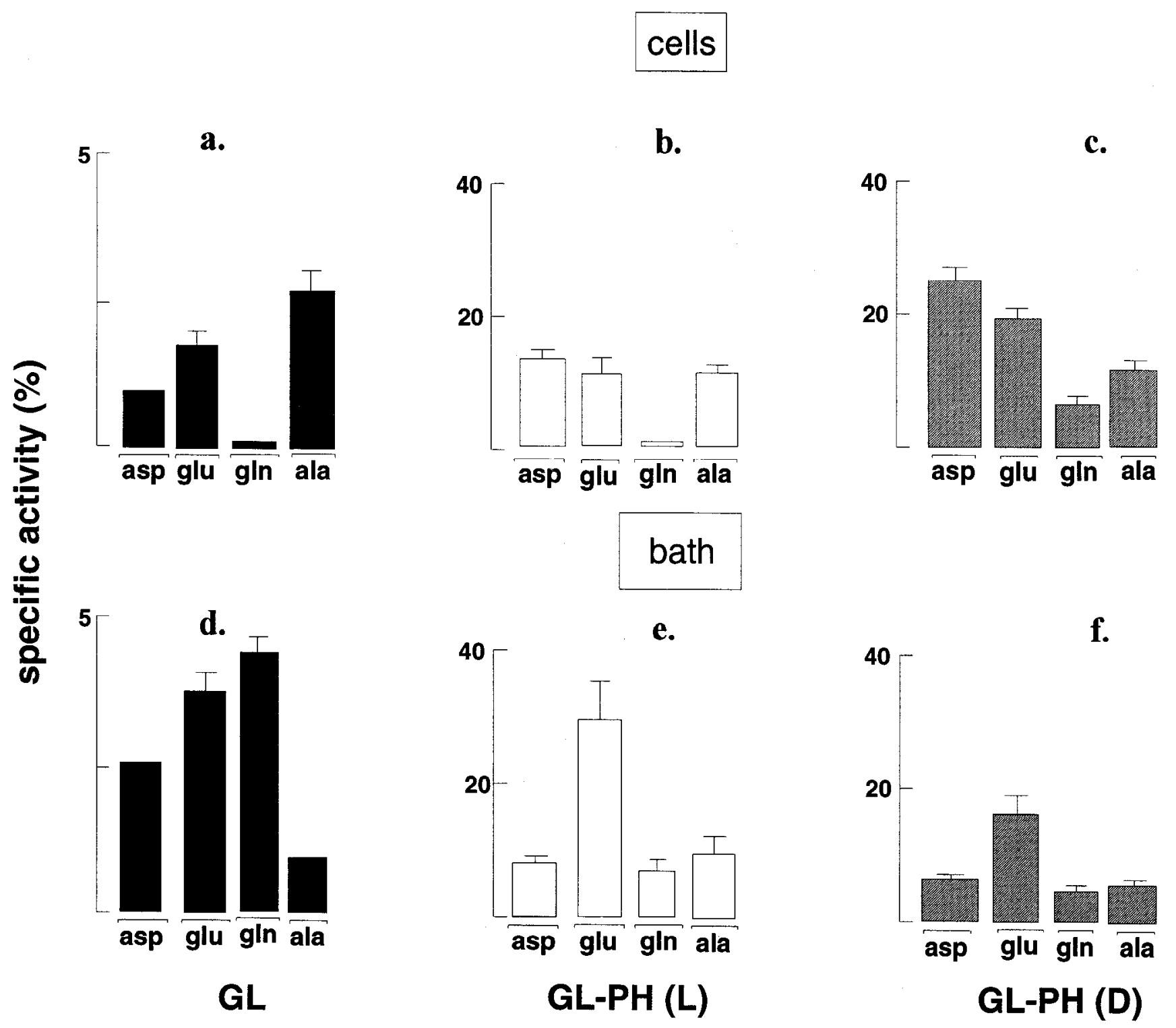

Figure 8. Specific activity (s.a.) of amino acids formed from ${ }^{14} \mathrm{C}(\mathrm{U})$-glucose by Müller cells and the cell complex of Figure 7 . Upper panels, inside the cells; lower panels, in the corresponding baths. Note the difference in scale between the left panels and the other panels.

The release of lactate, presumably with $\mathrm{H}^{+}$(Spencer and I ehninger, 1976), is expected to accomplish two important functions in Müller cells: first, it may prevent acidification of the cell interior, and second, enable the electron acceptor in the oxidation of glyceraldehyde-3P, that is, $\mathrm{NAD}^{+}$, to be regenerated and glycolysis to proceed (Halperin et al., 1969; Hochachka and Mommsen, 1983). A plasma membrane proton-linked lactate cotransporter has previously been described in brain glia (Walz and Mukerji, 1988); since this carrier can also transport pyruvate (Spencer and Lehninger, 1976; Poole et al., 1989), this may explain why we found some radiolabeled pyruvate in the bath of solitary Müller cells.

Our results showing that solitary photoreceptors produce ${ }^{14} \mathrm{CO}_{2}$ from exogenous ${ }^{14} \mathrm{C}$-lactate shed light on studies of photoreceptor function and metabolism in isolated retina. For example, after the removal of exogenous glucose, the $b$-wave of the electroretinogram is rapidly affected, lactate production promptly falls, but there is little effect on oxygen consumption, in the rabbit retina (Ames et al., 1992). One interpretation is that lactate, which is then produced only from glycogen, sustains photoreceptor respiration, but that Müller cells, which contribute to the $b$-wave, depend on exogenous glucose for their normal function. Consistent with this interpretation is the prevalence of $\mathrm{H}-\mathrm{LDH}$, the isoenzyme favoring the transformation of lactate to pyruvate, in the retinal layers containing photoreceptors (Matchinsky, 1970). In this respect, the observation made by Ostroy et al. (1990) that pyruvate is unable to maintain the light-induced respiratory response of photoreceptors, in frog retina, may indicate that the transformation of lactate to pyruvate by H-LDH is essential for photoreceptor metabolism. Indeed, this transformation is accompanied by the production of $\mathrm{NADH}$, and NADH has been shown by Wald and Hubbard (1949) to support the reduction of retinaldehyde. Thus, one possible use of lactate could be in providing both pyruvate for mitochondrial oxidative metabolism and NADH for pigment recycling.

Solitary photoreceptors in our study produced also ${ }^{14} \mathrm{CO}_{2}$ from ${ }^{14} \mathrm{C}(\mathrm{U})$-glucose. In this regards, Hsu and Molday (1994) recently reported that photoreceptor outer segments produce both lactate 


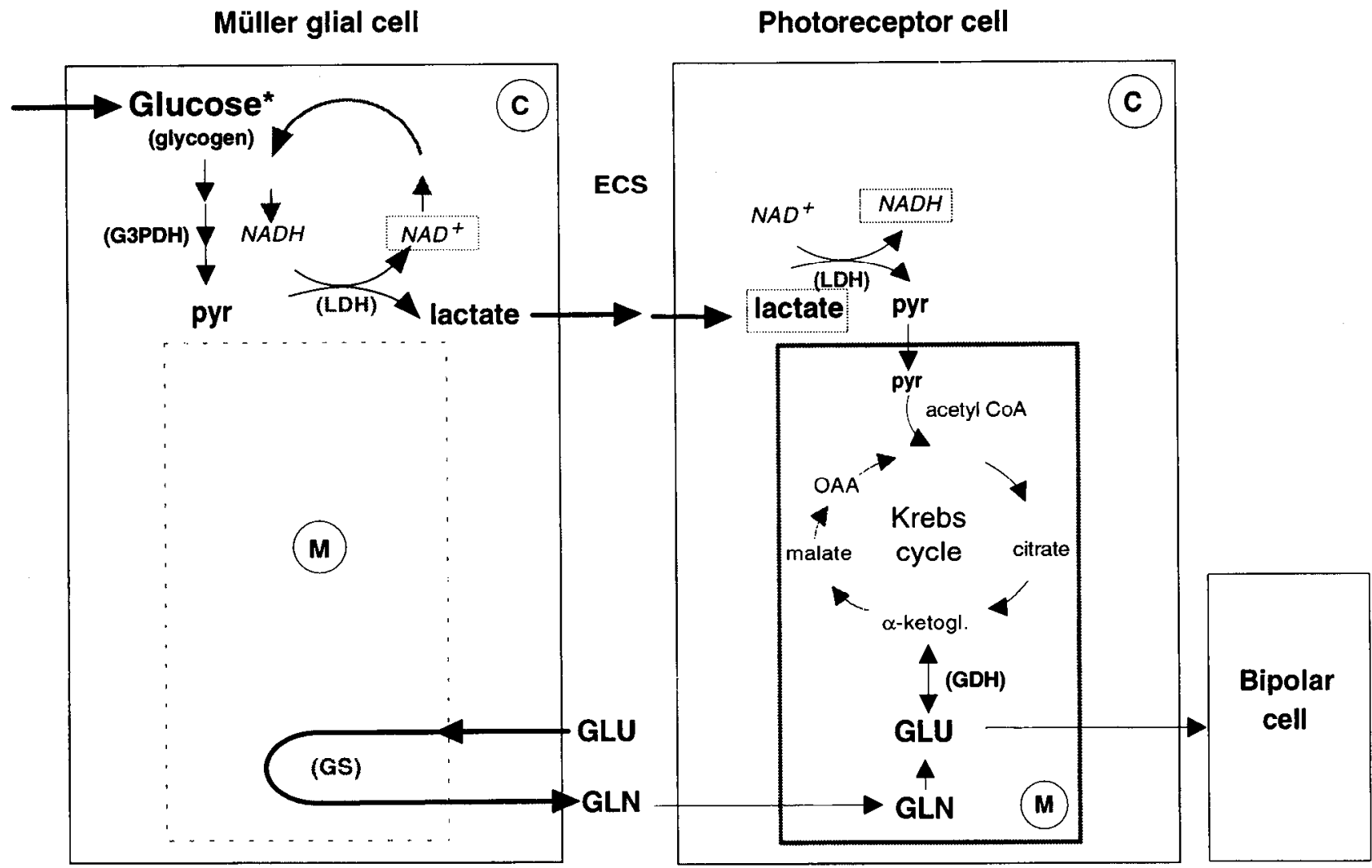

Figure 9. Proposed scheme of trafficking of lactate and amino acids between a Müller glial cell and a photoreceptor-neuron from guinea pig retina. In the presence of exogenous glucose and oxygen, lactate formed from glucose and/or glycogen in the Müller cell is released into the extracellular space $(E C S)$ and fuels the photoreceptor. $G 3 P D H$, glyceraldehyde 3-phosphate dehydrogenase; $L D H$, lactate dehydrogenase; $G S$, glutamine synthetase; $G D H$, glutamate dehydrogenase; circled $C$, cytoplasm; circled $M$, mitochondria.

from glucose and ${ }^{14} \mathrm{CO}_{2}$ from ${ }^{14} \mathrm{C}(\mathrm{U})$-glucose; they interpreted these results as indicating that both glycolysis and the pentose phosphate pathway are important for maintaining photoreceptor function. Considering that only one in six carbons from ${ }^{14} \mathrm{C}(\mathrm{U})$ glucose is converted to ${ }^{14} \mathrm{CO}_{2}$ through the pentose phosphate pathway, and that photoreceptors contain mitochondria, it seems most likely that the ${ }^{14} \mathrm{CO}_{2}$ production measured in our study reflects the rate of mitochondrial respiration, rather than the pentose phosphate pathway. Of course, we cannot exclude that ${ }^{14} \mathrm{C}$ glucose was first metabolized, in photoreceptor outer segments, to ${ }^{14} \mathrm{C}$-lactate, which then fueled mitochondrial respiration. Our result showing that the production of ${ }^{14} \mathrm{CO}_{2}$ from ${ }^{14} \mathrm{C}$-glucose was considerably lower than that from ${ }^{14} \mathrm{C}$-lactate is interpretable: lactate, once transformed to pyruvate, can then immediately enter the Kreb's cycle at the expense of less ATP input. In other words, the metabolism of lactate is energetically favored over that of glucose.

In the cell complex maintained in light, only a small portion of lactate was radiolabeled. This indicates that there was then probably a significant production of lactate from glycogen stores in Müller cells. This is in keeping with the results obtained by Dringen et al. (1993), who showed that glycogenolysis leads to the formation and release of lactate by cultured rat brain astrocytes, even in the presence of exogenous glucose. Since, in darkness, the s.a. of lactate decreased while the pool size of lactate increased in the bath of the cell complex, it appears possible that glycogenolysis in Müller cells was stimulated and that lactate was then released in larger amounts. Since Müller cells do not respond directly to changes in illumination and since photore- ceptors release their neurotransmitter, probably glutamate, in darkness, we envision the possibility that glutamate is a signal for glycogenolysis and lactate release by Müller cells. In this context, Pellerin and Magistretti (1994) have shown that the addition of $200 \mu \mathrm{M}$ glutamate to the bath of primary cultures of cerebral cortical astrocytes promotes within $30 \mathrm{~min}$ both the uptake of glucose and the stimulation of lactate release.

\section{Amino acid metabolism in Müller cells and photoreceptors}

Müller cells in the present study, like culturcd brain glia (c.g., Hertz, 1979), released glutamate into the bath. However, solitary Müller cells from salamander and glial cells from cultured hippocampal single-neuron microislands are also known to take up extracellular glutamate (Barbour et al., 1991; Mennerick and Zorumski, 1994). Based on the observation that intracellular glutamate was $\approx 1.5 \mathrm{mM}$ and $6 \mu \mathrm{M}$ extracellularly, it is unlikely that glutamate was released by reversal of the electrogenic uplake system (Szatkowski et al., 1990). We propose that this occurs by another, possibly electroneutral, transporter. The existence of such a transporter was already envisioned by Barbour et al. (1993).

We found that the s.a. of glutamine in solitary Müller cells was considerably smaller than that of glutamate, a finding previously observed in intact retinal tissue incubated in ${ }^{14} \mathrm{C}$-glucose (Morjaria and Voaden, 1979). Possibly, the transformation of glutamate to glutaminc, predominantly occurring in Müller cells (Riepe and Norenberg, 1977), takes place at a slow rate or alternatively, like for brain glia (Schousboe et al., 1993), there are two cellular pools of glutamine, of which only one is readily 
labeled from ${ }^{14} \mathrm{C}$-glucose. There was probably enough ATP for glutamine synthesis, since glucose was converted to lactate (see also Poitry-Yamate and Tsacopoulos, 1992). Therefore, we favor the second possibility, particularly since the s.a. of glutamine in the bath was much higher than in the cells and was of the same order as that of glutamate (N.B., a much higher s.a. in the bath than in the cells, was already observed with lactate). By the same token, we interpret the large rise in the s.a. of glutamine in the cell complex maintained in darkness as indicating that all pools of glutamine are then labeled from ${ }^{14} \mathrm{C}$-glucose and that there is an increased synthesis of glutamine.

Our results showing a $130 \%$ rise in the concentration of glutamate (final concentration $<6 \mu \mathrm{M}$ ) in the bath of the cell complex maintained in darkness was expected because photoreceptors are then depolarized and release neurotransmitter-glutanate (see, e.g., Massey, 1990). This was accompanied by a decrease in the s.a. of glutamate, which suggests that the additional amount released into the bath in darkness was weakly radiolabeled. This is to be expected if radiolabel is incorporated slowly into the neurotransmitter pool of glutamate (Wilkinson and Nicholls, 1988; Nicholls, 1989).

In conclusion, we have shown that lactate released from Müller glial cells is used to fuel mitochondrial oxidative metabolism in photoreceptor-neurons, even in the presence of millimolar concentrations of glucose. In addition, we developed a cell model of acutely isolated Müller glial cells still attached to photoreceptors from a mammalian retina and showed that this model responds to illumination: besides lactate, the metabolism of glutamate and glutamine were modulated by light and darkness. Because the specific activity of glutamate paralleled that of lactate, it will be of future interest to explore whether metabolites released by Müller glial cells, such as lactate, are involved in the regeneration of neurotransmitter pools of glutamate, as has been proposed for brain astrocytes (e.g., Hertz, 1979; Shank and Campbell, 1983; Schousboe et al., 1993).

\section{References}

Ahmed J, Braun RD, Dunn R Jr, Linsenmeier RA (1993) Oxygen distribution in the macaque retina. Invest Ophthalmol Vis Sci 34:516521 .

Altschuler RA, Mosinger JL, Harmison GG, Parakkal MH, Wenthold RJ (1982) Aspartate aminotransferase-like immunoreactivity as a marker for aspartate/glutamate in guinea pig photoreceptors. Nature 298:657-659.

Ames A III, I.i Y, Heher FC, Kimble CR (1992) Energy metabolism of rabbit retina as related to function: high energy cost of $\mathrm{Na}^{+}$transport. J Neurosci 12:840-853.

Babel J, Stangos N (1973) Essai de corrélation entre l'ERG et les ultrastructures de la rétine. I. Action du monoiodoacétate. Arch Ophthalmol (Paris) 33:297-312.

Barbour B, Brew H, Attwell D (1991) Electrogenic uptake of glutamate and aspartate into glial cells isolated from the salamander (Ambystoma) retina. J Physiol (Lond) 436:169-193.

Barbour B, Magnus C, Szatkowski M, Gray PTA, Attwell D (1993) Changes in $\mathrm{NAD}(\mathrm{P}) \mathrm{H}$ fluorescence and membrane current produced by glutamate uptake into salamander Müller cells. J Physiol (Lond) 466:573-597.

Biernbaum MS, Bownds MD (1985) Frog rod outer segments with attached inner segment ellipsoids as an in vitro model for photoreceptors on the retina. J Gen Physiol 85:83-105.

Dringen R, Gebhardt R, Hamprecht B (1993) Glycogen in astrocytes: possible function as lactate supply for neighboring cells. Brain Res 623:208-214.

Halperin ML, Connors HP, Relman AS, Karnovsky ML (1969) Factors that control the effect of $\mathrm{pH}$ on glycolysis in leukocytes. J Biol Chem 244:384-390.
Harris CK, Tigane E, Hanes CS (1961) Quantitative chromatographic method. Can J Biochem Physiol 39:439-451.

Haugh LM, Linsenmeier RA, Goldstick TK (1990) Mathematical models of the spatial distribution of retinal oxygen tension and consumption, including changes upon illumination. Ann Biomed Eng 18:1936.

Hertz L (1979) Functional interactions between neurons and astrocytes I. Turnover and metabolism of putative amino acid transmitters. Prog Neurobiol 13:277-323.

Hochachka PW, Mommsen TP (1983) Protons and anaerobiosis. Science 219:1391-1397.

Hogan MJ, Alvarado JA, Weddell JE (1971) Histology of the human eye, pp 557. Philadelphia: Sanders.

Hsu S-C, Molday RS (1994) Glucose metabolism in photoreceptor outer segments. J Biol Chem 269:17954-17959.

Krebs HA (1972) The Pasteur effect and the relations between respiration and fermentation. In: Essays in biochemistry, Vol 8. Biochemical society (Campbell PN, Dickens F, eds), pp 1-34. New York: Academic.

Kuwabara T, Cogan DG (1961) Retinal glycogen. Arch Ophthalmol 66:96-104.

Larrabee MG (1983) Lactate uptake and release in the presence of glucose by sympathetic ganglia of chicken embryos and by neuronal and nonneuronal cultures prepared from these ganglia. J Neurochem 40:1237-1250.

Larrabee MG (1992) Extracellular intermediates of glucose metabolism: fluxes of endogenous lactate and alanine through extracellular pools in embryonic sympathetic ganglia. J Neurochem 59:10411052

Lolly RN, Lee RH, Chase DG, Racz E (1986) Rod photoreceptor cells dissociated from mature mice retina. Invest Ophthalmol Vis Sci 27: 285295

Markwell MAK, Haas SM, Tolbert NE, Bieber LL (1981) Protein determination in membrane and lipoprotein samples: manual and automated procedures. Methods Enzymol 72:296-303.

Massey SC (1990) Cell types using glutamate as a neurotransmitter in the vertebrate retina. Prog Retinal Res 9:399-425.

Matchinsky FM (1970) Energy metabolism of the microscopic structures of the cochlea, the retina, and the cerebellum. In: Biochemistry of simple neuronal models (Costa E, Giacobina E, eds), pp 217-243. New York: Raven.

McKenna MC, Tildon JT, Stevenson JH, Hopkins IB (1993) Differences in lactate transport and metabolism in synaptic terminals and astrocytes. J Neurochem 61:S243.

Mennerick S, Zorumski CF (1994) Glial contributions to excitatory neurotransmission in cultured hippocampal cells. Nature 368:59-62.

Morjaria B, Voaden MJ (1979) The formation of glutamate, aspartate and GABA in the rat retina: glucose and glutamine as precursors. $J$ Neurochem 33:541-551.

Nicholls DG (1989) Release of glutamate, aspartate, and gamma-aminobutyric acid from isolated nerve terminals. J Neurochem 52:331341.

Ostroy SE, Svoboda RA, Wilson MJ (1990) A stage in glycolysis controls the metabolic adjustments of vertebrate rod photoreceptors upon illumination. Biochem Biophys Res Commun 168:155-160.

Pellerin L, Magistretti PJ (1994) Glutamate uptake into astrocytes stimulates aerobic glycolysis: a mechanism coupling neuronal activity to glucose utilization. Proc Natl Acad Sci USA 91:10625-10629.

Polyak SL (1941) Neuroglia of the retina. In: The retina, pp 343-365. Chicago: University of Chicago.

Poitry-Yamate CL, Tsacopoulos M (1991) Glial (Müller) cells take up and phosphorylate ${ }^{3} \mathrm{H}$-2-deoxy-D-glucose in a mammalian retina. Neurosci Lett 122:241-244.

Poitry-Yamate CL, Tsacopoulos M (1992) Glucose metabolism in freshly isolated Müller glial cells from a mammalian retina. J Comp Neurol 320:257-266.

Poole RC, Halestrap AP, Price SJ, Levi AJ (1989) The kinetics of transport of lactate and pyruvate into isolated cardiac myocytes from guinea pig. Biochem J 264:409-418.

Reichenbach A, Schneider H, Leibnitz L, Reichelt W, Schaaf P, Schumann R (1989) The structure of rabbit retinal Müller (glial) cells is adapted to the surrounding retinal layers. Anat Embryol (Berl) 180: 71-79.

Riepe RE, Norenberg MD (1977) Müller cell localization of glutamine synthetase in rat retina. Nature 268:654-655. 
Schousboe A, Westergaard N, Sonnewald U, Petersen SB, Huang R, Peng L, Hertz L (1993) Mctabolic intcractions between astrocytes and glutamatergic neurons. I. Net synthesis of TCA cycle constituents and compartmentation of glutamate metabolism in astrocytes. J Neurochem 61:S242.

Schurr A, West CA, Rigor BM (1988) Lactate-supported synaptic function in the rat hippocampal slice preparation. Science 240:1326-1328.

Shank RP, Campbell GLeM (1983) Metabolic precursors of glutamate and GABA. In: Glutamine, glutamate, and GABA in the central nervous system (Hertz L, Kvamme E, McGreer EG, Schousboe A, eds), pp 355-369. New York: Liss.

Spencer TL, Lehninger AL (1976) L-Lactate transport in Ehrlich ascites-tumor cells. Biochem J 154:405-414.

Szatkowski M, Barbour B, Attwell D (1990) Non-vesicular release of glutamate from glial cells by reversed electrogenic glutamate uptake. Naturc 348:443-446.

Tsacopoulos M, Veuthey A-L, Saravelos SG, Perrottet P, Tsoupras G
(1994) Glial cells transform glucose to alanine, which fuels the neurons in the honeybee retina. J Neurosci 14:1339-1351.

Uga S, Smelser GK (1973) Comparative study of the fine structure of retinal Müller cells in various vertebrates. Invest Ophthalmol Vis Sci 12:434-448.

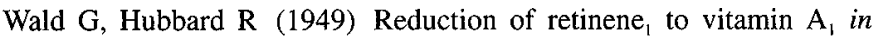
vitro. J Gen Physiol 32:367-389.

Walz W, Mukerji S (1988) Lactate release from cultured astrocytes and neurons: a comparison. Glia 1:366-370.

Wiesinger H, Dringen R, Hamprecht B (1993) Lactate transport in cultured neural cells. J Neurochem 61:S244.

Wilkinson R, Nicholls DG (1988) Compartmentation of $\mathrm{Ca}^{++}$-dependent pools of glutamate and aspartate in isolated cerebral cortical nerve terminals by isotopic exchange and fractionation. Biochem Soc Trans 16:879-880.

Winkler BS (1981) Glycolytic and oxidative metabolism in relation to retinal function. J Gen Physiol 77:667-692. 